\title{
CHANGES IN PHYSICAL QUALITY OF OXISOLS UNDER DIFFERENT MANAGEMENT SYSTEMS IN THE BRAZILIAN CERRADO
}

\author{
Carlos E. L. Feitosa ${ }^{1 *}$, Pedro H. dos S. Costa², Kamila C. de Meneses ${ }^{3}$, \\ Ulisses C. de Oliveira ${ }^{4}$, Maryzélia F. de Farias ${ }^{2}$
}

1* Corresponding author. Universidade Federal do Rio Grande do Sul/ Santa Maria - RS, Brasil.
E-mail: eduardo.linhares @ live.com | https://orcid.org/0000-0001-5785-2886

KEYWORDS
S index, land cover
change, physical
properties,
infiltration, soil
compaction.

\begin{abstract}
Soil compaction in agricultural areas has greatly increased in recent decades due to intensive farming practices, including short-cycle crops and machinery intensification. This study aimed to evaluate the impacts of management systems on the physical quality of a dystrophic Yellow Oxisol, in the Cerrado region of Brazil. Treatments consisted of five soil management systems, with five replications (native forest [control], slash-andburn agriculture, pasture, no-tillage, and conventional tillage). Data analysis was performed using a completely randomized experimental design. All systems were analyzed for soil density, macroporosity, microporosity, total porosity, hydraulic conductivity, infiltration, water retention curve, penetration resistance, and soil quality index (S index). The systems had significant effects on soil structure, and the evaluated properties responded well to changes promoted by them. No-tillage implementation raised soil resistance in the area previously damaged by intensive farming. Moreover, soils under pasture and slash-and-burn systems presented higher water retention in field capacity and higher $\mathrm{S}$ indexes, thus having a better structural quality.
\end{abstract}

\section{INTRODUCTION}

To achieve food security and meet world demand for food and energy, Brazil has expanded its agricultural boundaries with intensive use of machinery, inputs, and improved crop varieties. However, soils in these areas, which until the 1970s were considered non-agricultural, mainly in the Cerrado biome, have low fertility and high acidity (Fischer et al., 2018).

In the Brazilian Cerrado, Oxisols have shown some problems related to improper management practices, as these soils are highly susceptible to compaction under natural conditions, mainly by machinery traffic during rainy season (Severiano et al., 2011). The effects of heavy traffic compaction may persist for more than a decade and are especially unfavorable in highly moist soils (Guaman et al., 2016, Holthusen et al., 2018).

Agricultural exploration with unsustainable soil management practices is common in many developing countries. In this sense, concerns have been raised about impacts on soil physical properties, resulting in soil compaction (Medina et al., 2017; Caviglione, 2018). Among the physical properties related to compaction, soil resistance to penetration stands out for its high relationship with crop yields. The compaction promotes a mechanical impediment to root growth, which can be simulated fast and economically, besides generating a number of observations that allow analyze resolution spatial structural of the soil (Parahyba et al., 2019).

Currently, few studies on soil management in the Brazilian Cerrado and other dry areas have investigated how to reduce soil mechanical resistance to improve water storage. Our hypothesis is that areas under intensive use of machinery tend to undergo changes in their soil structure, causing aggregation fragmentation and soil compaction, hence reducing soil quality. Therefore, our study aimed to evaluate the impacts of different management systems on the physical quality of a dystrophic Yellow Oxisol in the Brazilian Cerrado.

${ }^{2}$ Federal University of Maranhão/ Chapadinha - MA, Brazil.

${ }^{3}$ FCAV- São Paulo State University/ Jaboticabal - SP, Brazil.

${ }^{4}$ Federal University of Ceará/ Fortaleza - CE, Brazil.

Area Editor: Murilo Aparecido Voltarelli

Received in: 3-25-2020

Accepted in: 7-6-2020 


\section{MATERIAL AND METHODS}

Field characteristics

This study was carried out in Chapadinha, Maranhão, Brazil (03 44' 27" S, 43 18' 44" W, 110-m altitude) from February to May 2015 (Figure 1). To add to our dataset, we also used the findings of Farias et al. (2017) on the soil physical properties on the same areas and under different management systems, from 2013 to 2014. Therefore, our findings add substantial new information and do not repeat the results already presented by this previous study.

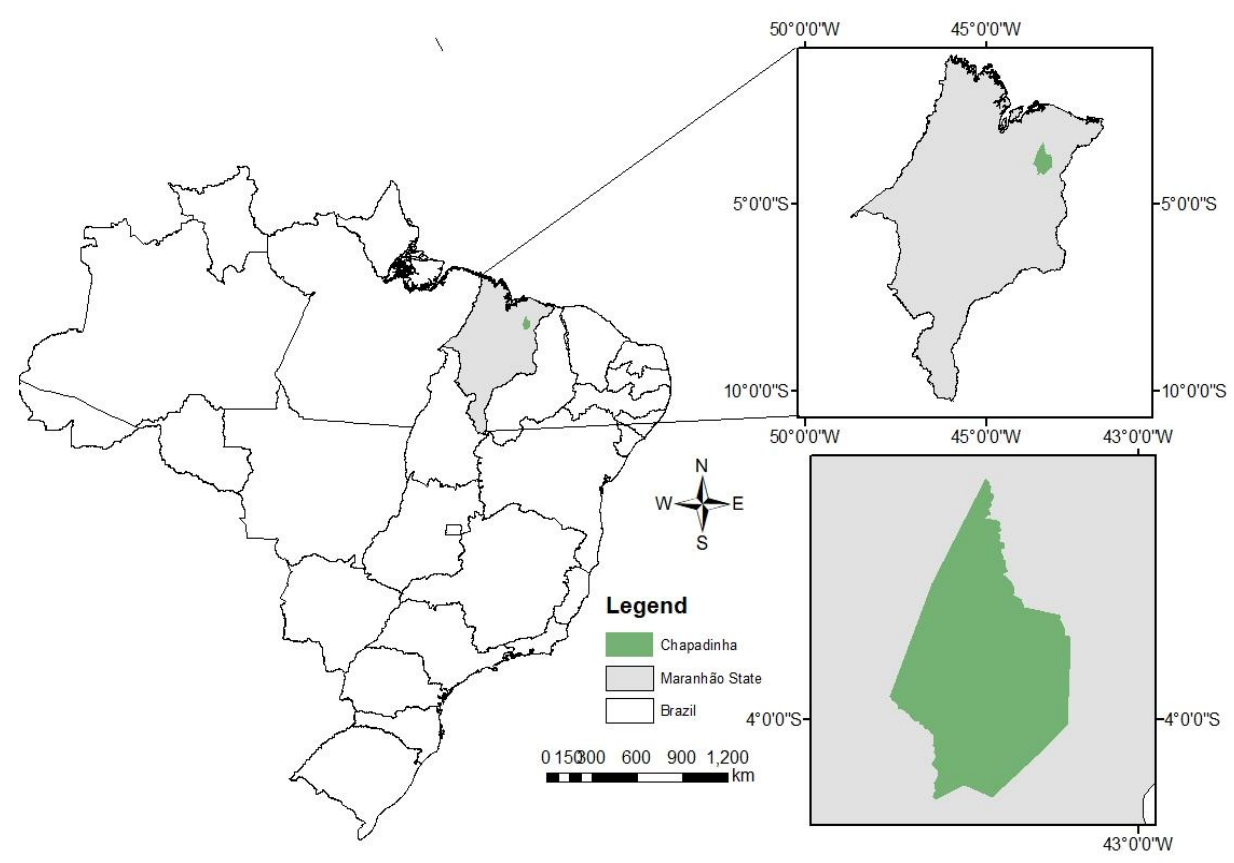

FIGURE 1. Study site location.

According to Thornthwaite \& Mather (1957), the local climate is defined as sub-humid megathermic, with great water deficiency in summer (C2s2A 'a'). Average annual rainfall is $1613 \mathrm{~mm}$, concentrated between January and May, with shortage from June to December. Average annual temperature is $28^{\circ} \mathrm{C}$ (Passos et al., 2016). The local soils are classified as dystrophic Yellow Oxisols (Santos, 2013; IUSS Working Group WRB, 2015) and are predominantly covered by Cerrado vegetation, with diverse floristic composition (Bandeira, 2013). Table 1 shows the chemical and physical characteristics of the soils under study.

TABLE. 1. Chemical and physical properties of soil under different management systems at the depth range of $0.0-0.10 \mathrm{~m}$.

\begin{tabular}{cccccc}
\hline Soil Management & $\mathrm{pH}$ & $\begin{array}{c}\mathrm{OM} \\
\mathrm{g} \mathrm{dm}^{-3}\end{array}$ & Sand & $\begin{array}{c}\text { Silt } \\
\mathrm{g} \mathrm{kg}^{-1}\end{array}$ & $\begin{array}{c}\text { Clay } \\
\text { Native forest }\end{array}$ \\
Conventional tillage & 4.1 & 21 & 810 & 70 & 120 \\
No-tillage & 4.8 & 19 & 800 & 80 & 120 \\
Slash-and-burn & 4.7 & 20 & 860 & 20 & 120 \\
Grassland & 4 & 25 & 610 & 210 & 280 \\
\hline
\end{tabular}

Legend: $\mathrm{pH}$ - hydrogenionic potential; OM - organic matter.

\section{Physical and physical-hydric soil parameters}

The experimental design was completely randomized, with five treatments and five replications. Each treatment consisted of a management system: conventional tillage (area grown with soybeans [Glycine max]), pasture (area under elephant grass pasture [Pennisetum purpureum]), slash-andburn agriculture (area deforested and burned before planting, then grown with manioc [Manihot esculenta]), no-tillage (soybeans cultivation over millet straw [Pennisetum glaucum]), and native forest (Cerrado). The study was carried out in situ by estimating the following parameters: resistance to penetration, moisture, bulk density, infiltration, and hydraulic conductivity of soils.
Deformed soil samples were collected from the depth range of $0.0-0.10 \mathrm{~m}$, using a probe-type auger. Retention curves were established by saturating the soil samples with water for 24 hours and determined using Richards chambers (Embrapa, 1997). Soil moistures were estimated at 6, 10, 30, $100,300,500$, and $1500 \mathrm{kPa}$. The sampled points used for retention curve were fitted using the equation proposed by Van Genuchten (1980). Infiltration speed was determined based on basic infiltration rate, using samples collected in situ and a constant flow permeameter (Guelph Permeameter model 2800). The infiltration rate is normally established as the volume of water passing the soil surface per unit of time $\left(\mathrm{mm} \mathrm{h}^{-1}\right)$. The soil samples used for hydraulic conductivity were collected randomly from five 5 -cm-diameter holes, 
opened at $15 \mathrm{~cm}$ depth. The sampling was performed as homogeneously as possible so that data were not altered. Then, hydraulic loads were calibrated using a beaker to confirm the fit of hydraulic load by the Guelph permeameter. Lastly, the hydraulic conductivity was measured using the method of Elrick et al. (1989).

Soil microporosity was determined by the method of Richards and Embrapa (1997), whereas macroporosity was obtained by the difference between total porosity and microporosity. Resistance to penetration was tested using a Stolf impact penetrometer. The tests were performed in the five management systems up to a maximum depth of 0.40 $\mathrm{m}$, subdivided into three different layers $(0.10,0.20$, and $0.40 \mathrm{~m}$ depths). To be used as soil resistance to penetration data, the number of impacts required to trespass the layers (0.00 - 0.10, $0.10-0.20$, and $0.20-0.40 \mathrm{~m}$ ) were converted to $\mathrm{mPa}$, as described by Stolf (1991). During penetration resistance tests, soil samples were taken from the depth ranges of $0.0-10 \mathrm{~m}$ and $0.10-0.20 \mathrm{~m}$. The samples were placed in closed capsules, conditioned in a thermal box, and taken to the laboratory for moisture content determination by the gravimetric method.

\section{Statistical analyses}

Means of each soil depth were compared by the Tukey's test $(p<0.05)$. Statistical analyses were carried out through Info Stat software (Di Rienzo et al. 2011). A multivariate hierarchical clustering was used to gather treatments into groups by Ward's method, comparing their similarities by Euclidean distance (Sneath \& Sokal, 1973). A first-order linear principal component analysis (PCA), using an orthogonal linear transformation, was performed to separate the correlated and uncorrelated variables, using a vector matrix to reduce dimensionality (Cruz et al., 2011) and facilitate dataset interpretation (Borůvka et al. 2005). The PCA is a type of indirect gradient analysis that evaluates data total variability (Ter Braak \& Smilauer, 2002). The biplot rule was used for the vector analysis (Kroonenberg, 1995).

\section{RESULTS AND DISCUSSION}

Soil resistance to penetration, retention curve, physical and physical-hydric parameters

Although grain size was predominantly sandy, penetration resistance values were above $2 \mathrm{mPa}$ in all tested soils and depths. Under pasture and native forest, resistance to penetration was relatively lower (Figure 2). This suggests that organic matter increases from vegetation and animal presences and plant density reduction from grass planting decrease soil resistance to penetration, corroborating the findings of Cherubin et al. (2016).

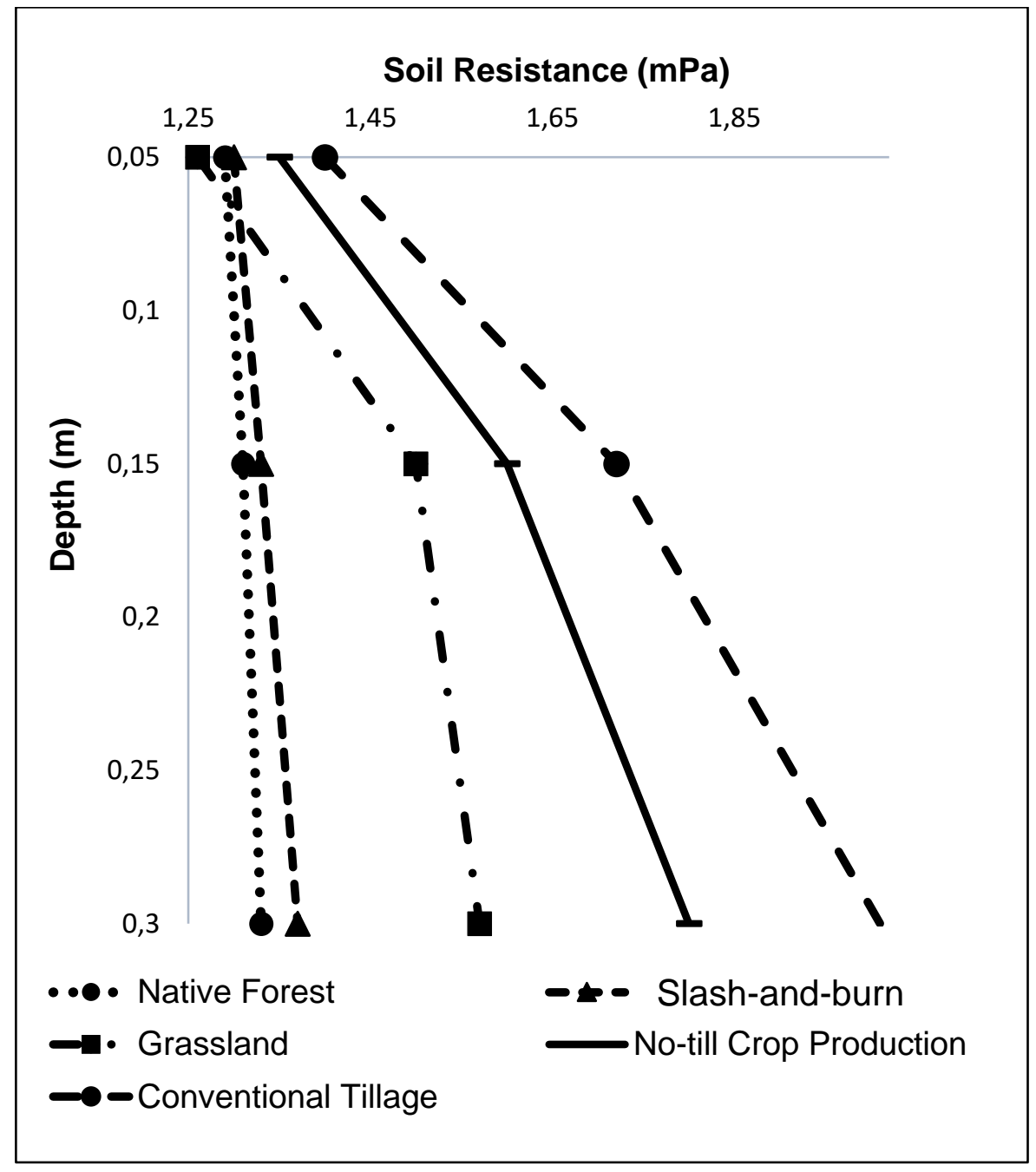

FIGURE 2. Soil resistance to penetration at three soil depths five management systems. 
Ordóñez et al. (2018) concluded that planting of grasses is the factor that most reduced soil compaction and maintained its physical quality. In our study, the soil under slash-and-burn agriculture showed the highest resistance to penetration. This is because the use of fire to clean fields reduces soil humidity and increases its cohesion, hence increasing resistance to penetration. Under low humidity, soil resistance to penetration varies widely and can lead to soil-metal friction by soil cohesion and adhesion increases after moisture loss (Silva et al., 2016). Conventional and notillage areas showed penetration resistance increases at all depths and humidity reductions compared to the others. This might have been caused by intense machinery traffic. These findings corroborate those of Farias et al. (2017), who verified resistance to penetration increases due to changes in soil structure at surface and subterranean layers. In other words, this can be related to aggregation changes in the soil, which is mechanically fragmented by its excessive use, thus resulting in soil densification and compaction.

The slash-and-burn area had lower apparent soil density, whereas conventional tillage showed the highest value. It may have been due to a porous space reduction by management system, with consequences on the other parameters (Table 2). When compared to the conventional system, no-till had soil densities relatively lower. This difference can be attributed to the OM accumulation in notill areas, resulting in longer reductions in soil compaction and increases in soil aggregation (Guaman et al., 2016).

TABLE 2. Averages of soil bulk density (Ds, in $\mathrm{kg} \mathrm{dm}^{-3}$ ), infiltration rate (IR, in $\mathrm{cm} \mathrm{min}^{-1}$ ), hydraulic conductivity $\left(\mathrm{K}, \mathrm{cm} \mathrm{h}^{-1}\right)$, total porosity (\%), macroporosity (\%), and microporosity (\%) of soils under different management systems, Chapadinha, Maranhão state, Brazil, 2015.

\begin{tabular}{|c|c|c|c|c|c|c|}
\hline Management System & Ds & IR & $\mathrm{K}$ & Macroporosity & Microporosity & Total Porosity \\
\hline & $\left(\mathrm{g} \mathrm{cm}^{-3}\right)$ & $\left(\mathrm{cm} \mathrm{min} \min ^{-1}\right)$ & $\left(\mathrm{cm} \mathrm{h}^{-1}\right)$ & $-\cdots$ & $(\%)-$ & - \\
\hline Native Forest & $1.27 \mathrm{c}$ & $0.29 \mathrm{bc}$ & $0.00633 \mathrm{a}$ & $42 ; 5 \mathrm{bc}$ & $5.5 \mathrm{a}$ & $52 \mathrm{a}$ \\
\hline $\begin{array}{c}\text { Conventional } \\
\text { no-tillage }\end{array}$ & $1.53 \mathrm{bc}$ & $0.04 \mathrm{a}$ & $0.002039 \mathrm{a}$ & $35 \mathrm{c}$ & $7.3 \mathrm{a}$ & $42.0 \mathrm{ab}$ \\
\hline No-tillage & $1.39 \mathrm{~b}$ & $0.10 \mathrm{ab}$ & $0.002682 \mathrm{a}$ & $42 ; 7 \mathrm{ab}$ & $4.8 \mathrm{a}$ & $47.5 \mathrm{a}$ \\
\hline Slash-and-burn & $1.13 \mathrm{a}$ & $0.15 \mathrm{abc}$ & $0.006974 \mathrm{a}$ & $48 \mathrm{a}$ & $8.6 \mathrm{a}$ & $49.8 \mathrm{a}$ \\
\hline Grassland & $1.17 \mathrm{bc}$ & $0.31 \mathrm{c}$ & $0.005901 \mathrm{a}$ & $49.2 \mathrm{a}$ & $6.6 \mathrm{a}$ & $55.8 \mathrm{a}$ \\
\hline $\mathrm{CV}(\%)$ & 10.5 & 70.19 & 19 & 12.81 & 14.80 & 12.34 \\
\hline
\end{tabular}

Means followed by the same letter in the treatment and between them do not differ statistically from each other by the Tukey's test at $5 \%$ probability $(p<0.05)$.

The highest infiltration speed was observed in soil under pasture followed by native forest and slash-and-burn areas. These areas, in turn, were significantly different from conventional and no-tillage systems. Therefore, OM input and vegetation root system improve aggregate stability and aeration in soils (macroporosity), increasing water infiltration and hydraulic conductivity. Zhipeng et al. (2018) obtained similar results and concluded that higher $\mathrm{OM}$ and moisture levels enhance soil infiltration and hydraulic conductivity, thus allowing water storage and a more effective infiltration.

It is worth noting that when intensive agricultural practices are conducted in an Oxisol, macropores are severely affected by the first passages of agricultural machinery. This occurs because Oxisols are highly susceptible to compaction (Carducci et al., 2011), and thus have their infiltration and hydraulic conductivity reduced. Nevertheless, installation of a no-till system increases soil resilience against anthropogenic effects.

Each management system provided unique differences in soil water retention curves (Figure 3). Therefore, soil properties were affected and water contents in samples of the different applied potentials reduced. By contrast, Farias et al. (2017) found that soil horizons with the same textural class do not always present similar curves. Thus, soil textural class influence should also be considered. Moreover, other factors such as rainfall, soil sampling techniques, wildlife, and machinery traffic can affect the shapes of the water retention curves. 


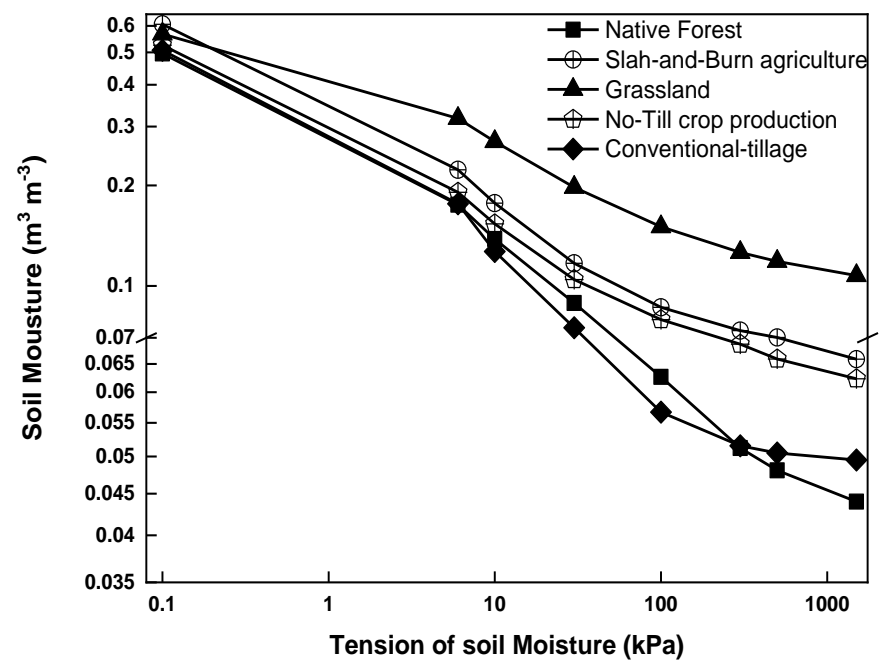

FIGURE 3. Water retention curves for different soil management systems.

At saturation point, the soil under slash-and-burn system reached the highest moisture level, followed by pasture, other management systems, and finally native forest area. Regarding the water retention curve performance of the other applied potentials, we observed that soil under pasture maintained a higher water content than the other systems. What can be associated with a greater number of micropores, whose size and shape help retain water by capillarity. Microporosity is mainly related to the clay content in a given textural class, which, due to the colloidal sizes, predispose formation of such micropores (Silva et al., 2018).

The soil under no-tillage system showed greater water retention. This may be due to its higher OM contents at surface layers, what is typical of such management, allowing greater soil aggregation and hence resistance (Rezanezhad et al., 2016). The conventional tillage area tended to have low water retention along points, which remained until the so-called permanent wilting point. This may be derived from soil structure destruction by intensive use of agricultural machinery.

Second Carducci et al., (2011), macropores are affected by intense machine traffic and soil disturbance increasing susceptibility soil to compaction (Carducci et al., 2011). Especially Amazon soils undergo changes in their physical and structural quality and become automatically susceptible to degradation when submitted to agricultural machinery management and trafficability of tractors and implements. Soil compaction in conventional tillage increased soil matrix influence on water movement, that is, soil matrix potential increased due to transformation of macropores into micropores and, thus, increasing water retention (Gomes et al., 2019).

\section{$S$ index and multivariate analysis}

The values of $S$ indexes obtained in the soil management systems (Table 3) are clearly related to soil porosity and bulk densities (Caviglione, 2018).

TABLE 3. Averages of S index for each soil management systems.

\begin{tabular}{ccc}
\hline System & Textural Class & S Index \\
\hline Native forest & Loamy sand & -0.11 \\
Conventional Tillage & Loamy sand & -0.08 \\
No-tillage & Loamy sand & -0.10 \\
Pasture & Clay loam & -0.15 \\
Slash-and-burn & Clay loam & -0.14 \\
\hline
\end{tabular}

The highest $\mathrm{S}$ index was obtained in pasture followed by slash-and-burn, native forest, no-till, and conventional tillage. In this sense, the introduction of fire was very recent. Providing to a lesser extent, degradation soil physical properties, still preserving its structure. Xu et al. (2017) observed a close relationship between $S$ index and soil organic matter, therefore, such factor is fundamental for preservation, remediation, and formation of aggregates, and hence improvements in soil physical properties that directly influence $S$ index values.

Both conventional and no-tillage areas had lower S indexes compared to the others. We noted that these areas also showed higher soil densities and reductions in macroporosity and total porosity. This can be seen by a steepest slope in the soil water retention curve, resulting in a quality index reduction. It occurs because of frequent changes in soil structure, that is, improper use of soil favoring degradation of its structural quality (Valipour, 2014; Naderi-Boldaji \& Keller, 2016).

Despite the intensive management, the studied areas showed good physical conditions for plant growth, given their $\mathrm{S}$ indexes above 0.056 . These $\mathrm{S}$ indexes presented in porous systems are within the limits for arable soils, indicating soils with preserved structure, even that under conventional tillage (Farias et al., 2017). 
Figure 4 shows the hierarchical cluster analysis dendrogram for the soil managements. Conventional and no-tillage systems were grouped in the same cluster since they had the smallest Euclidean distances, thus similar in terms of soil properties. This occurred because the notillage system has been just recently implemented in the area. Conversely, the soil properties of this cluster were quite different from those of the native forest area. The second cluster comprised the native forest, slash-and-burn, and pasture areas, which had the largest Euclidean distances compared to those of the first group, i.e., they had similar soil properties.

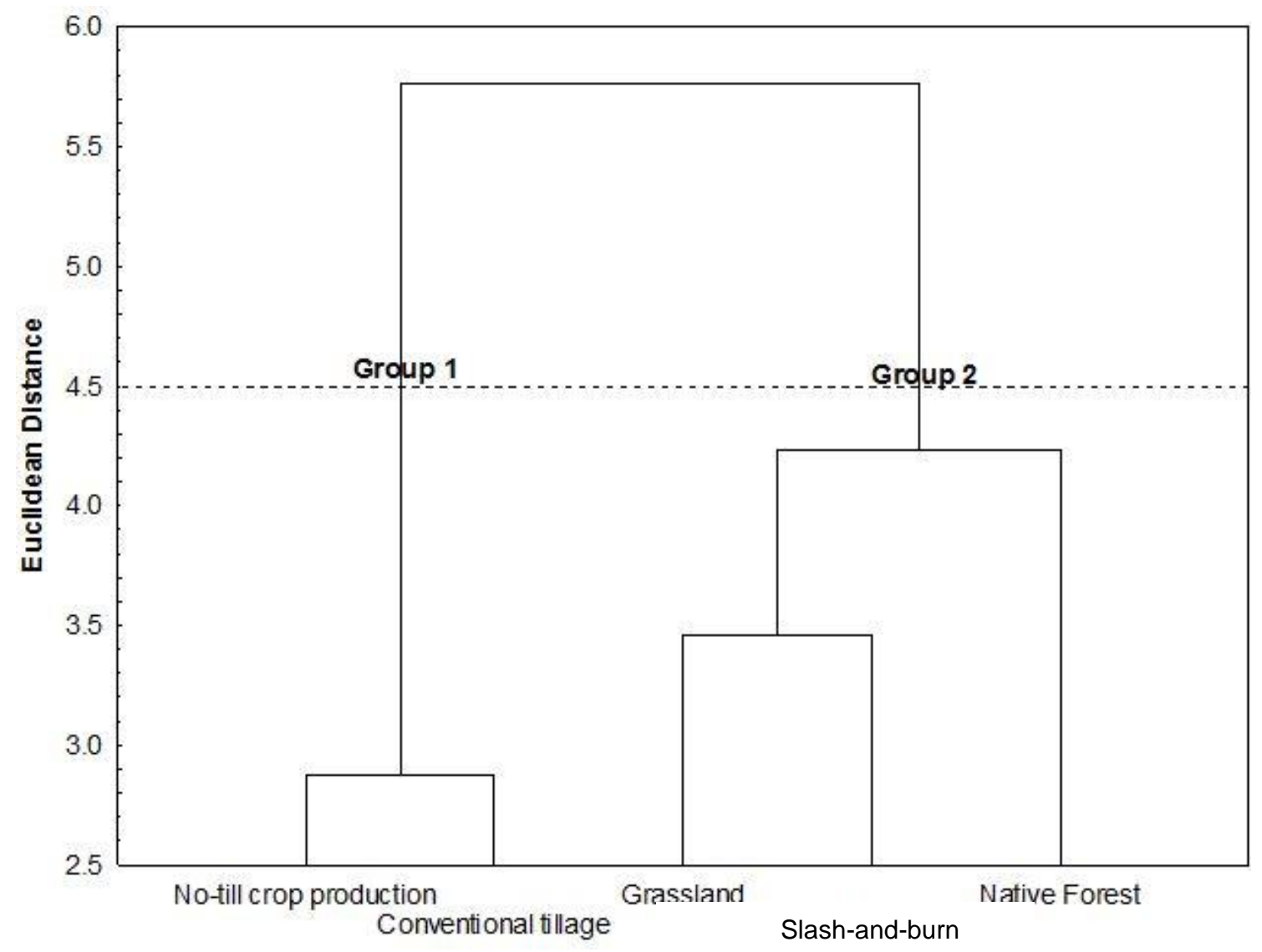

FIGURE 4. Dendrogram showing the hierarchy of clusters for soil management systems as a function of soil physical properties.

The management systems explained $84.61 \%$ of the variability in soil physical properties, as already reported in the literature (Ji et al., 2013). In the principal component 1
(CP1), the management systems remained explaining the largest part of the variation in soil physical properties (Figure 5). 


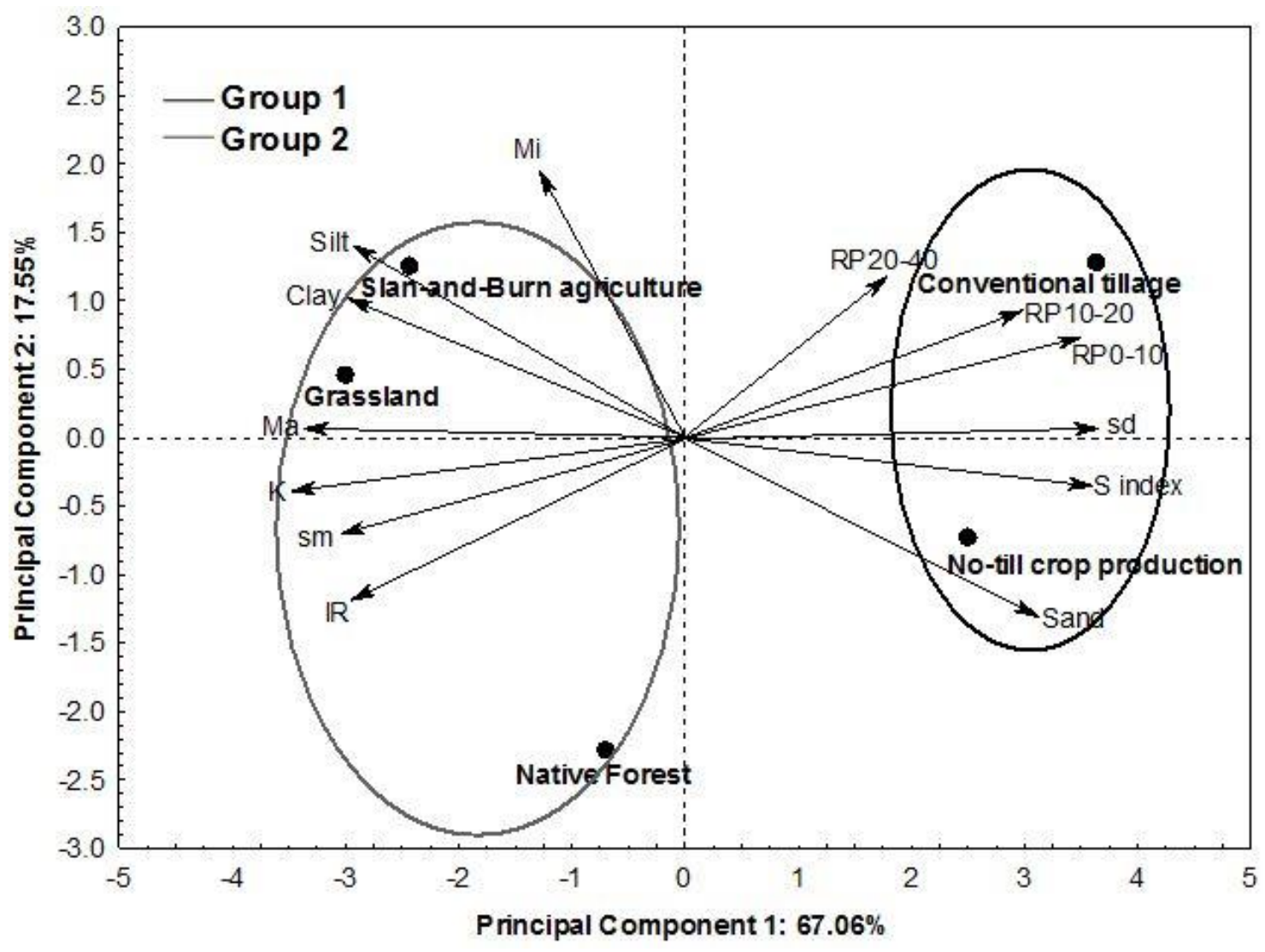

FIGURE 5. Biplot of the principal component analysis for soil properties and management systems.

A relationship of direct dependence was observed among the following physical properties: resistance to penetration (RP) 20-40, RP 10-20, RP 0-10, soil bulk density, S-index, and sand. All of them were designed in the same direction of the conventional and no-tillage systems. On the other hand, a relationship of indirect dependence was registered between the same properties with microporosity, silt, clay, macroporosity, K, US, and VI, but now in the opposite direction, and on the side of the slash-and-burn, pasture, and native forest systems.

The above-mentioned relationships indicate that conventional tillage areas had greater resistance to penetration. This is because these areas are mostly compacted by machinery traffic, compressing soil air by fragmentation of aggregates, thus reducing soil quality. Conventional tillage was also greatly influenced by the properties S index and sand content. Such finding proves that a proper soil management can improve soil quality, especially for sandy soils. The pasture and slash-and-burn systems had a relationship with microporosity, clay, and silt, once clayey soils have smaller amounts of macropores and larger amounts of micropores, which makes infiltration slower than in sandy soils that have larger pores (Parahyba et al., 2019). The native forest area was mostly influenced by hydraulic conductivity, soil moisture, and infiltration speed, which might have been due to accumulation of organic materials on the soil, thus increasing infiltration.

Regarding the complexity of soil variables, multivariate analysis proved to be suitable for understanding the system structure jointly, identifying variables that most contribute to changes in soil physical properties. As discriminative as univariate analysis procedures are, it was clear that they were unable to establish relationships between the studied variables.

\section{CONCLUSIONS}

Soil management systems have significant effects on the structure of Oxisol, and the studied properties responded well to changes promoted by them. A no-tillage system improves parameters that increase soil resistance, after damaged by previous intensive agriculture use. The soils under pasture and slash-and-burn systems showed higher water retention in field capacity and high $\mathrm{S}$ indexes, indicating these soils have a better structural quality.

\section{ACKNOWLEDGMENTS}

This study was financially supported by the Foundation for Research and Scientific and Technological Development of Maranhão - (Fundação de Amparo à Pesquisa e ao Desenvolvimento Científico e Tecnológico do Maranhão - FAPEMA), enabling the development of this study, besides providing a scholarship to the first author.

\section{REFERENCES}

Bandeira ICN (2013) Geodiversidade do estado do Maranhão. Teresina, CPRM, 294 p.

Boruuvka L, Vacek O, Jehlička J (2005) Principal component analysis as a tool to indicate the origin of potentially toxic elements in soils. Geoderma 128:289-300.

Carducci CE, Oliveira GC, Severiano EC, Zeviani WM (2011) Modelagem da curva de retenção de água de Latossolos utilizando a equação duplo van Genuchten. Revista Brasileira de Ciência do Solo 35:77-86.

Caviglione JH (2018) S-Index as an indicator of physical quality in soils of the Paraná state. Revista Brasileira de Engenhria Agrícola e Ambiental 22(7):458-464. 
Cherubin MR, Karlen DL, Franco ALC, Tormena CA, Cerri CEP, Davies CA, Cerri CC (2016) Soil physical quality response to sugarcane expansion in Brazil. Geoderma 267:156-168.

Cruz JS, Assis Júnior RN, Matias SSR (2011) CamachoTamayo, J.H. Spatial variability of an Alfisol cultivated with sugarcane. Ciencia e Investigacion Agraria 38:155-164.

Di Rienzo JÁ, Casanoves F, Balzarini MG, Gonzalez L, Tablada M, Robledo CW (2011) InfoStat. Universidade Nacional de Córdoba.

Elrick DE, Reynolds WD, Tan KA (1989) Hydraulic conductivity measurements in the unsaturated zone using improved well analyses. Groundw. Monit. Remediat 9:184-193.

Embrapa - Empresa Brasileira de Pesquisa Agropecuária (1997) Manual de métodos de análises do solo. Rio de Janeiro, Ministério da Agricultura e do Abastecimento, 2 ed.

Farias MF, Feitosa CEL, Rodrigues KDM, Teixeira LC, Furtado MB, Parra-Serrano LJ (2017) Impact of management on the physical attributes of a dystrophic yellow latosol. Journal of Agricultural science 9:217-225.

Fermino MH, Kämpf NA (2006) Impedância mecânica de substratos para plantas submetidas a diferentes tensões hídricas. Pesquisa Agropecuária Gaúcha 25-30.

Fischer P, Pöthig R, Gücker B, Venohr M (2018) Phosphorus saturation and superficial fertilizer application as key parameters to assess the risk of diffuse phosphorus losses from agricultural soils in Brazil. Science Total Enviroment 630:15151527.

Gomes RP, Bergamin, AC, Silva LS, Campos MCC, Cazetta JO, Coelho AP, Souza EDD (2019) Changes in the physical properties of an Amazonian Inceptisol induced by tractor traffic. Chilean Journal of Agricultural Research 79(1):103-113.

Guaman V, Båth B, Hagman J, Gunnarsson A, Persson P (2016) Short time effects of biological and inter-row subsoiling on yield of potatoes grown on a loamy sand, and on soil penetration resistance, root growth and nitrogen uptake. European Journal of Agronomy, 80:55-65.

Holthusen D, Brandt AA, Reichert JM, Horn R (2018) Soil porosity, permeability and static and dynamic strength parameters under native forest/grassland compared to notillage cropping. Soil Tillage Research 177:113-124.

Ji B, Zhao Y, Mu X, Liu K, Li C (2013) Effects of tillage on soil physical properties and root growth of maize in loam and clay in central China. Plant, Soil and Environment 59(7):295-302.

Kroonenberg PM (1995) Introduction to biplots for G x E Tables. Research Report n51.

IUSS Working Group WRB (2015) World reference base for soil resources 2014, update 2015 International soil classification system for naming soils and creating legends for soil maps. FAO, World Soil Resources Reports 106.

Medina H, Jong van Lier Q, García J, Ruiz ME (2017) Regional-scale variability of soil properties in Western Cuba. Soil Tillage Research 166:84-99.
Naderi-Boldaji M, Keller T (2016) Degree of soil compactness is highly correlated with the soil physical quality index S. Soil and Tillage Research 159:41-46.

Ordóñez I, López FI, Kemp DP, Constanza AD, Rainer H, Zúñiga F, Dec D, Dörner J (2018) Effect of pasture improvement managements on physical properties and water content dynamics of a volcanic ash soil in southern Chile. Soil and Tillage Research 178:55-64.

Parahyba RDV, Araújo, Sbalmeida BG, Neto FCR, Sampaio VSV, Caldas AM (2019) Water retention capacity in Arenosols and Ferralsols in a semiarid area in the state of Bahia, Brazil. Anais da Academia Brasileira de Ciencias 91(4).

Passos M, Zambrzycki GC, Pereira RS (2016) Balanço hídrico e classificação climática para uma determinada região de Chapadinha-MA. Revista Brasileira de Agricultura Irrigada 10:758-766.

Rezanezhad F, Price JS, Quinton WL, Lennartz B, Milojevic T, Van Cappellen P (2016) Structure of peat soils and implications for water storage, flow and solute transport: A review update for geochemists. Chemical Geology 429:75-84.

Santos HG dos (2013) Sistema Brasileiro de Classificação de Solos. Brasília, Embrapa, 3 ed. ver ampl. 353 p.

Severiano EC, Oliveira GC, Júnior D, Souza M, Costa KAP, Silva FG, Ferreira Filho SM (2011) Structural changes in latosols of the cerrado region: I-relationships between soil physical properties and least limiting water range. Revista Brasileira de Ciência do Solo 35:773-782.

Silva MLN, Libardi PL, Gimenes FHS (2018) Soil water retention curve as affected by Sample Height. Revista Brasileira Ciência do Solo, Viçosa 42.

Silva WM, Bianchini A, Cunha CA (2016) Modeling and correction of soil penetration resistance for variations in soil moisture and soil bulk density. Revista Engenharia Agrícola 36:449-459.

Sneath PHA, Sokal RR (1973) Numerical taxonomy. San Francisco, Freeman, 573 p.

Ter Braak CJF, Smilauer P (2002) CANOCO reference manual and CanoDraw for Windows user's guide: software for canonical community ordination (version 4.5).

Thornthwaite CW, Mather JR (1957) Instructions and tables for computing potential evapotranspiration and the water balance. Climatology 10(3).

Valipour M (2014) Drainage, waterlogging, and salinity. Archives Agronomy of Soil Science 60(12):1625-1640.

Van Genuchten MT (1980) A closed-form equation for predicting the hydraulic conductivity of unsaturated soils. Society of America Journal 44:892-898.

Xu C, Xu X, Liu M, Yang J, Zhang Y, Li Z (2017)

Developing pedotransfer functions to estimate the $\mathrm{S}$-index for indicating soil quality. Ecological Indicators 83:338-345.

Zhipeng L, Donghaob M, Wei H, Xuelin L (2018) Land use dependent variation of soil water infiltration characteristics and their scale-specific controls. Soil and Tillage Research 178-139-149. 